Mary F. Hicks, Sacramento, California.

Jane E. Hukill, director, Widener University Library, Wilmington, Delaware.

Richard D. Johnson, director of libraries, State University College, Oneonta, New York.

Sheila M. Laidlaw, university librarian, Harriet Irving Library, University of New Brunswick, Fredericton.

Lois P. Mills, documents and legal reference librarian, Western Illinois University, Macomb.

Orthella Polk Moman, head of technical services, Jackson State University Library, Mississippi.

Joan Neumann, executive director, New York Metropolitan Reference and Research Library Agency, Brooklyn, New York.

Ruth J. Person, associate dean, Catholic University of America, Washington, D.C.

Sandra K. Peterson, Government Documents Center, Yale University, New Haven, Connecticut.

Lelia G. Rhodes, dean of libraries, Jackson State
University, Mississippi.

Carlton Rochell, dean of libraries, New York University.

Joseph A. Rosenthal, university librarian, University of California, Berkeley.

Marvin H. Scilken, director, Orange Public Library, New Jersey.

Judith A. Sessions, university librarian, California State University, Chico.

Marilyn J. Sharrow, chief librarian, University of Toronto, Ontario.

Carol A. Turner, chief librarian, Jonsson Library of Government Documents, Stanford University, California.

Susan J. Vaughn, associate librarian for collection development, Brooklyn College Library, New York.

Robert A. Walter, government documents librarian, Pittsburg State University, Kansas.

Louella V. Wetherbee, executive director, Amigos Bibliographic Council, Dallas, Texas.

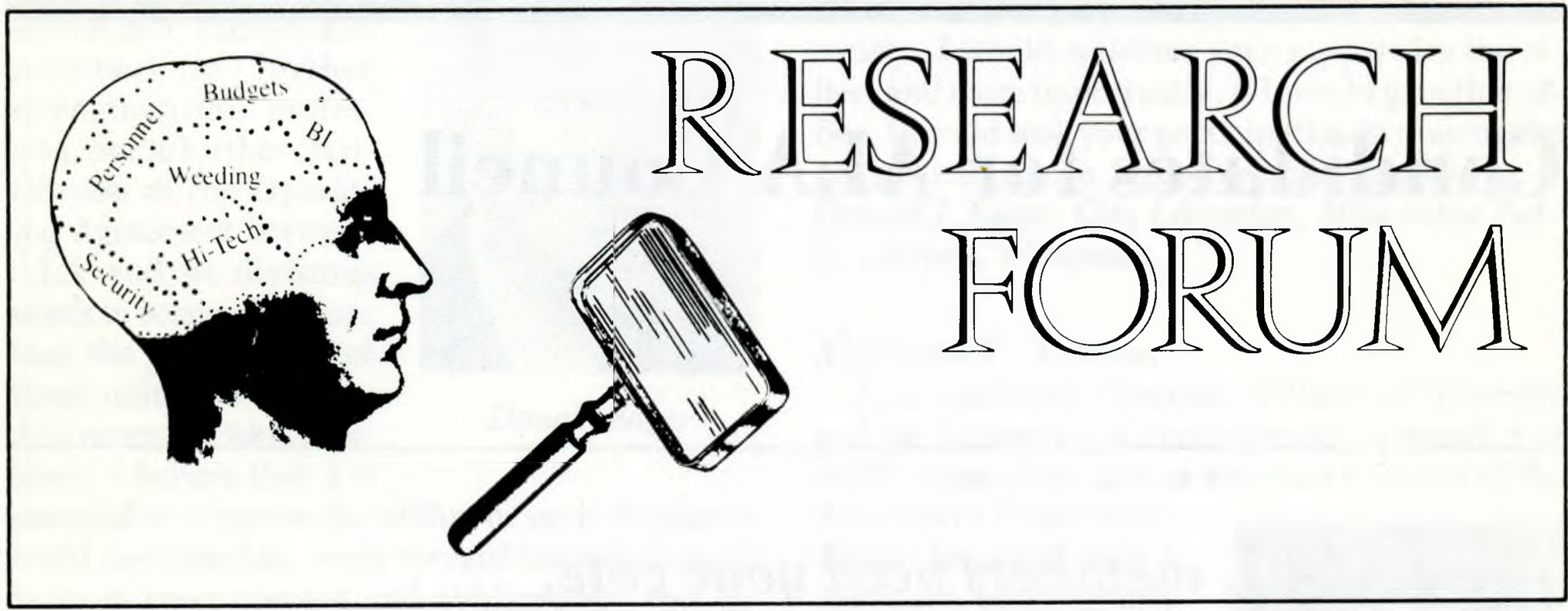

\title{
Stimulating quality research: Starting with the basics
}

\author{
By Dorothy J. Anderson \\ Chair, ACRL Research Development Committee
}

ACRL's new Research Development Committee is launching a plan to stimulate superior research among academic librarians. The plan is based on three beliefs.

1) Many astute library directors recognize research as an opportunity to:

-enhance the library's status in the university and in the profession;

- lift staff morale; and

- investigate persistent problems scientifically.

2)Many bright academic librarians would enjoy doing research if they had:

- administrative support (time, money, recognition);
- confidence in their ability;

-help and training;

3) As an incentive to do quality research, potential researchers need training designed to diffuse fears, build confidence and to develop a researcher's mindset and ability.

The Research Development Committee therefore proposes a mechanism to link library directors, new researchers, and basic training. These foundation blocks form the necessary base for an invisible college-a network of new researchers around the country-who can produce research of superior quality in an encouraging atmosphere. 


\section{Step I. Research clinics}

We invite academic library directors to nominate and support one or two "potential researchers" on their staffs to attend ACRL's first national Research Clinic in Chicago on July 8, 1985.

The Clinic will: -demonstrate the diagnosis and treatment of a researchable problem;

- stimulate a positive attitude toward research; and

- suggest ways to team up with academic colleagues.

Use the Research Clinic form below:

As a library director, I nominate staff members:

Name

Name
Title

to participate in ACRL RESEARCH CLINIC I, July 8, 1985

and agree to support them by offering $\square$ comp time $\square$ travel funds

other

Phone

\section{Institution}

Address

Mail to: Dorothy J. Anderson, Chair

ACRL Research Development Committee

120 Powell Library, UCLA

405 Hilgard Avenue

Los Angeles, CA 90024

\section{Step II. An Idea Bank}

We invite each of you to send us your best research idea: think of a professional problem or question that concerns you (20 words or less). The idea can be phrased as a question, a problem, or an issue. For example, "Which students mutilate books?" or "Book mutilation is a problem," etc. We will show how to turn ideas into researchable questions at Research Clinic I; then we will put your ideas into an Idea Bank available to all researchers through ACRL and the Office for Library Research. (We are working now on the possibility of an Electronic Idea Bank through ALANETwatch for an announcement.) Meanwhile, use the Idea form on page 183.

\section{Step III. Consultants}

After we identify a core of new researchers who begin to investigate new questions, another impor- tant element can be added. Volunteer Research Consultants from each library school could critique proposals and (without a commitment to the project) assist with research design and review first drafts.

Research Clinic II in New York in 1986 will tentatively present model research partnerships between libraries and library educators-such as those supported by the Council on Library Resources.

Everyone can get into this act-directors, potential researchers, seasoned researchers, idea people, other research units at ALA, and library educators.

The Research Development Committee is eager to hear from you. We are: Dorothy J. Anderson (chair), Assistant Professor, Graduate School of Library and Information Science, University of California, 405 Hilgard Avenue, Los Angeles, CA 90024; Sara Fine, Associate Professor, School of Library and Information Science, 606 LIS Building, 


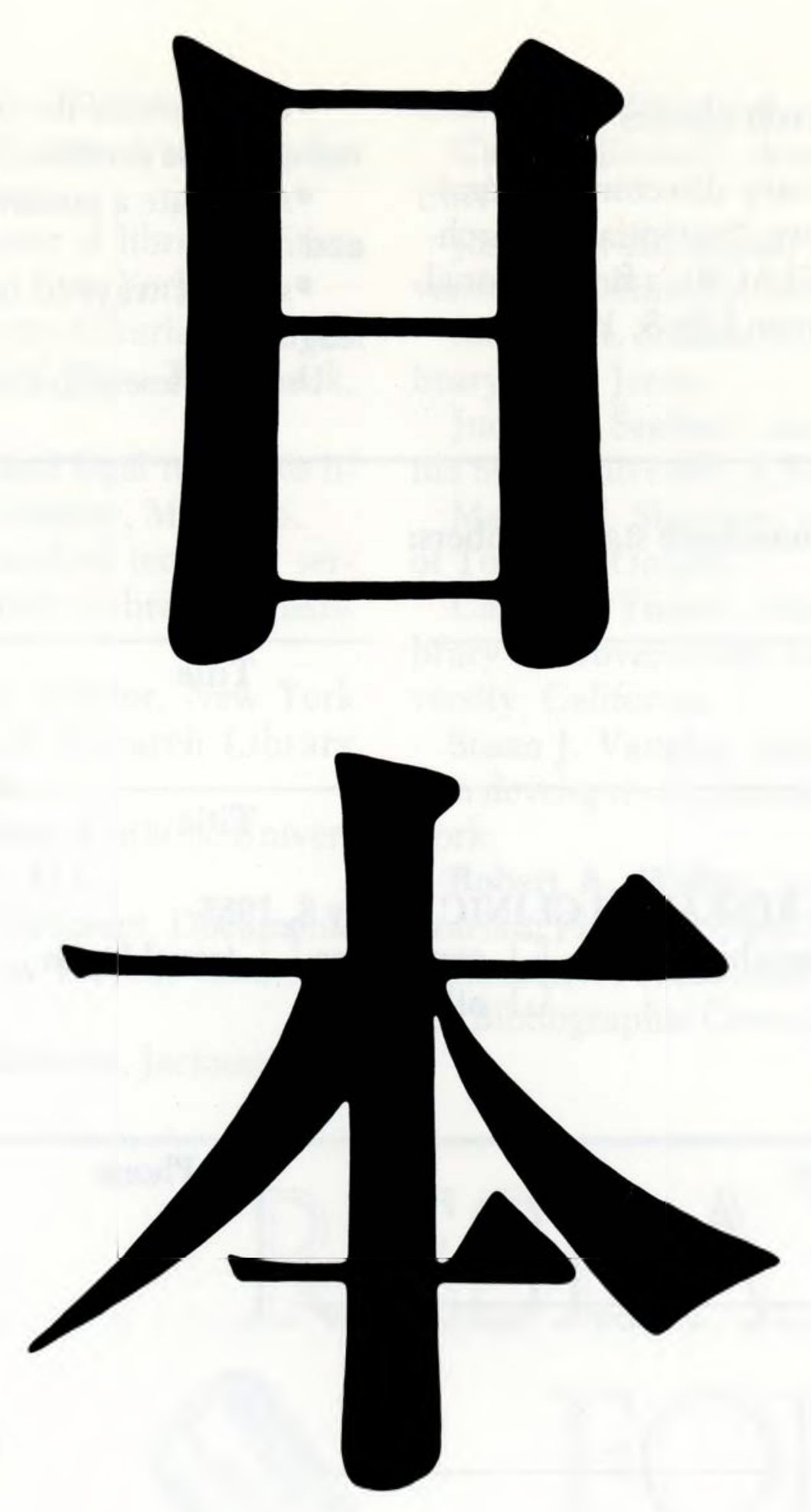

\section{HOW TO READ THE JAPANESE.}

It's actually quite simple. You can acquire the most current, vital findings of Japanese research-in a way that's far easier than reading them in Japanese.

Because now there's the Japanese Technical Information Service, and it's available from UMI, a Xerox information company.

When your organization subscribes to JTIS, you receive monthly abstracts in English from more than 750 Japanese publications. All areas of applied tech- nology and business in which Japan is prominent are covered, including microelectronics, computer technology, biotechnology, aerospace engineering, quality control, business management, finance, ceramics, defense, and more.

Now you can finally learn about the latest Japanese advances in technology and business-without spending years learning how to read Japanese.

For more information about JTIS, call UMI toll-free at 1-800-521-0600.

\section{University 300 North Zeeb Road \\ Microfilms Ann Arbor, Michigan 48106 International (313) 761-4700}


Here's my research idea

I've done some research and I'd like to be part of a researcher's network

I've never done research and I'd like to attend Research Clinic I, July 8, 1985 in Chicago

Name

Title

Institution

Address

Telephone

Mail to: Dorothy J. Anderson, Chair

ACRL Research Development Committee

120 Powell Library, UCLA

405 Hilgard Avenue

Los Angeles, CA 90024

University of Pittsburgh, Pittsburgh, PA 15260; Mary George, Head of General Reference Division, Princeton University Library, Princeton, NJ 08544; James May, Dean of Information Services,

\section{Folger Theater to remain open}

The Folger Shakespeare Theater in Washington's Folger Shakespeare Library will be kept open for at least the next two years. In January its trustees had announced plans to close the theater at the end of its current season, but protests by members of Congress and civic leaders led to reconsideration.

The Theater will be provided with $\$ 150,000$ annually for two years by the trustees of Amherst College, Massachusetts, who administer funds from the Henry Clay and Emily Jordan Folger estates for the Library. To this will be added $\$ 130,000$ from the Library each year for overhead costs, and $\$ 50,000$ a year from an anonymous donor.

Private supporters from the community will then operate an independent board to run the theater's five plays per season and raise money for future deficits.

The Folger Shakespeare Library houses the largest collection of first folios in existence. In 1970 the Theater was added to present stage productions of Shakespeare plays.
California State University Library, Chico, CA 95929-0290; Steve Stoan, Head of Reference, Wichita State University Libraries, Box 68, Wichita, KS 67208.

\section{Conference paper deadlines extended}

Deadlines for submitting research papers, position papers, or idea briefs for the Baltimore Conference have been extended. The new dates are:

June 1-Notice of Intention to Submit a Paper or Brief due.

July 8-Completed manuscript due.

Camera-ready copy of accepted papers is still due November 15.

The focus of the 1986 ACRL National Conference will be to explore the theme, "Energies for Transition." The Conference aims to identify the nature of the transitions facing librarians and to suggest energies to meet them, both through the informal gathering of colleagues and formal programs.

For more information, see $C \triangleleft R L$ News, January 1985, p. 17 .

Notices of Intention should be sent to: ACRL Contributed Papers, c/o Danuta A. Nitecki, Office of Public Services, McKeldin Library 2124, University of Maryland, College Park, MD 20742. 